\author{
K.M. Shaimerdenova ${ }^{1}$, E.R. Schrager ${ }^{2}$, A.S. Tussypbaeva ${ }^{1}$, Zh.K. Nausharban ${ }^{1}$ \\ ${ }^{I}$ Ye.A. Buketov Karaganda State University, Kazakhstan; \\ ${ }^{2}$ National Research Tomsk State University, Russia \\ (E-mail: gulzhan.0106@mail.ru)
}

\title{
Investigation of heat exchange processes in vertically arranged heat exchangers
}

\begin{abstract}
Today, in many countries, electricity is produced in a variety of ways, depending on current trends. The use of heat pump technology in heat energy development is one of the most efficient energetic methods. In order to save energy, it makes possible to use heat of subsurface water, reservoirs, natural water flows, etc. The environmental effectiveness of this technology is that it helps to prevent greenhouse gas emissions caused by combustion. Therefore, it is the use of gas and liquid fuel in the system that is one of the main and actual problems of operating heat pumps, but not replacement of old boilers. It will not only reduce fuel consumption, but also reduce carbon dioxide emissions to the atmosphere. In the laboratory of «Unconventional Energy Sources», experiments were conducted on an assembled test bench to study heat exchange processes taking place in a ground heat exchanger. The temperature distribution data in the vicinity of a U-shaped ground heat exchanger was experimentally specified. They showed temperature changes around the pipe in the ground. Using the obtained data, dependency graphs were constructed. The temperature change depending on different moisture content of the sand was determined. The temperature variation dependency graph with temperature difference of different moisture content was plotted.
\end{abstract}

Keywords: heat transfer, heat exchange, ground, temperature sensor, heat exchanger, energy.

\section{Introduction}

At present, the search and active use of new alternative energy sources in many developed countries of the world are considered as vital, strategically necessary resources ensuring the prospective development of the economies of these countries. Therefore, the modern development of the energy sector of the Republic of Kazakhstan is characterized by a radical rearrangement of the fuel and energy sector structure. This is due to the increase in prices of fossil fuel in the world market, the aggravation of environmental problems. One of the effective ways to solve this problem is the introduction of less energy-consuming new technology, which will be a source of non-traditional renewable energy.

The advantage of applying heat supply technology using non-conventional energy sources over technologies with traditional energy sources is the reduction of energy consumption during heat supply, new opportunities for an environmentally friendly and autonomous heat supply system.

To use low-grade ground heat it is necessary to prepare well holes to install heat exchangers of a heat pump. Various drilling methods can be used to obtain horizontal and vertical wells. A horizontal ground heat exchanger is installed near the building, at a shallow depth. The use of such ground heat exchangers is limited by the size of the available area. The vertical ground heat exchanger works effectively in almost all types of geological media, with the exception of low thermal conductivity grounds, for example, dry sand or dry gravel. Systems with vertical ground heat exchangers got widespread use.

The most effective and widely used among such devices are heat pumps [1]. Heat pumps are our source of energy for heating and hot water supply. Heat carrier is a very convenient, cost-effective and environmentally friendly heating system. The main difference from other generators is that they generate thermal energy using, for example, electricity, gas, and so on. In the production of heat using heat pumps, $75 \%$ of the energy comes from the environment, and the remaining $25 \%$ is electrical energy for the operation of the heat pump compressor. In other words, the owner of the heat pump saves $70 \%$ of the costs.

Today, heat pumping units are an effective tool for energy saving, as prices for various types of fuel and electricity have increased. The use of heat pumping units for the needs of heat supply makes it possible to use significant economic and environmentally friendly technologies that do not cause carbon dioxide and other harmful substances emission to the atmosphere. Since the first use of heat pumps in a heating system, gas boilers have proved that they are economically unable to compete. As a result, heat-absorbing units have tended to replace other types of heat supply. 
As a low-cost heat source in heat pumping units, industrial and clarified domestic wastewater, geothermal and artesian heat, subsurface heat and solar energy heat and so on are used.

The heat carrier is installed horizontally and vertically under the ground. Vertical heat exchangers in the depths make it possible to use low grade thermal energy of the ground (10-20 m from the ground level). The heat carrier circulates through pipelines laid in the ground at a depth of 25-200 m. The heat of the environment is supplied with water and antifreeze. The solidification point is approximately $13{ }^{\circ} \mathrm{C}$. This keeps the solution from freezing during the process of operation [2].

The solution is pumped by a circulating pump and is used to heat the building using a heat pump and heat insulation, therefore the surface of the heat exchanger must be adapted to the influence of sunlight. It is made of heat-exchanging polyethylene or metal-reinforced plastic pipes below the surface. Their diameter ranges from 25 to $40 \mathrm{~mm}$.

In this regard, the purpose of the work is to study the temperature pattern of sandy soil around the heat exchange tubes. To achieve the goal, the time-temperature change was studied at different mass concentrations of water. The time history graphs of experimental works on dry sandy ground of different moisture contentare presented.

\section{Research technique}

The research methods were the analysis of domestic and foreign methods of using heat pumps, obtaining parameters of drilling well holes by mechanical and electric pulse method intended for the installation of heat exchangers by an experimental method and the method for research of the heat exchange process of underground heat exchangers. Heat exchanger well holes, made by means of electric hydropulse technology, can improve heat exchange processes in heat exchangers and increase heat removal [3].

Installed in ready-made well holes using electric hydropulse technologies, exchanger in the laboratory of «Unconventional energy sources» experiments were conducted on the assembled test bench to study heat exchange processes in the ground heat exchanger. The initial parameters were as follows:

Initial ground temperature: $t=10^{\circ} \mathrm{C}$;

Environment temperature: $t=23^{\circ} \mathrm{C}$;

The diameter of the U-shaped vertical ground heat exchanger: $D / d=32 / 25 \mathrm{~mm}$.

The experiments were carried out at different ground conditions for a closer approximation to the natural conditions of the ground heat exchanger.

The main requirements for the quality of the experimental setup were uninterrupted power supply sources of constant thermal energy at the well and the possibility of taking high temperature accuracy and heat consumption metering. In order to monitor the temperature, heat sensors were installed vertically along the pipe and in the middle of the U-shaped heat exchanger. They show temperatures in the ground and in the vicinity of the pipe. During the experiment, heat sensors measured the temperature in several locations, in particular at different distances from the U-shaped pipe, at the outlet and at the U-bend pipe turn.

The readings of temperature sensors inside the well hole were found using the Temp Keeper program. The Temp Keeper program is designed to monitor and control the temperature and moisture content of various objects or environments in which sensors will be placed. This program makes it possible to visually observe the changes taking place, as well as to monitor whether the specified parameters are normal, warning you with an audible signal if necessary.

Figure 1 shows a test bench for studying the process of heat transfer in vertical heat exchangers.

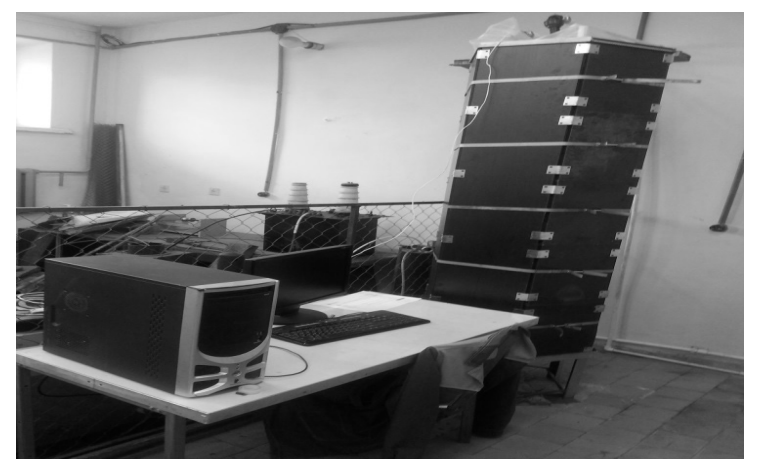

Figure 1. The experimental test bench 
Figure 2 shows a diagram of the test bench for studying the heat exchange processes in ground heat exchangers.

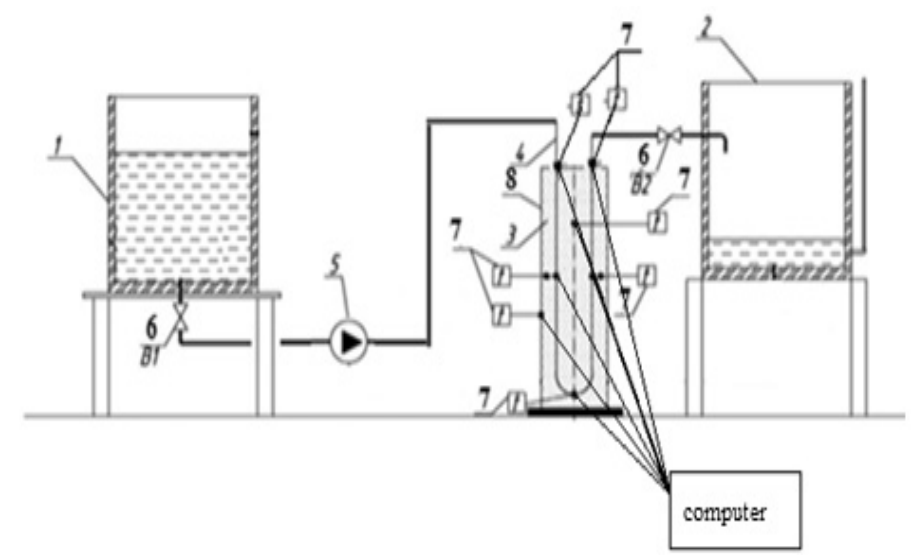

1 - water storage tank; 2 - tank for measurements; 3 - ground; 4 - U-shaped vertical heat transfer section with ground; 5 - circulation pump; 6 - valve (B1, B2); 7 - electronic sensors for temperature control; 8 - wooden case

Figure 2. The diagram of the test bench for studying heat exchange processes in ground heat exchangers

\section{Investigation results}

Initially, the temperature change at different radial distances in dry soil was determined. During the flow of cold water through the U-shaped pipe at a speed of $0.098 \mathrm{~m} / \mathrm{s}$, readings of thermal sensors located at different distances were taken every 10 minutes. They showed temperature changes around the pipe in the ground. Using the data obtained during the tests, dependency graphs were constructed. Figure 3 shows the change in temperature history distribution [4].

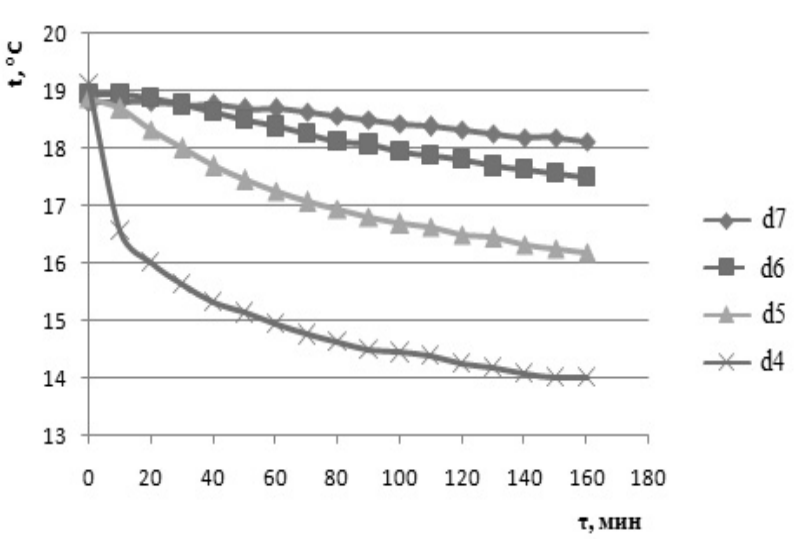

$a$ - the pipe junction area

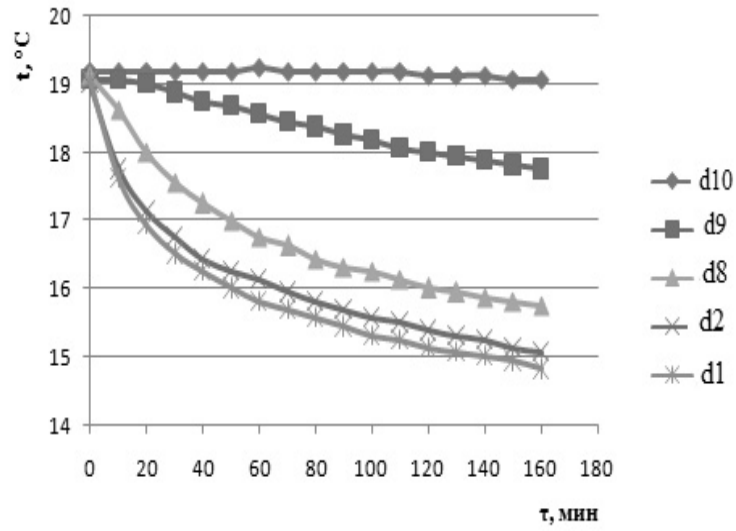

$b$ - the pipe outlet area

Figure 3. Change in temperature history distribution (dry soil)

The ground temperature around the pipe over the course of time falls relatively faster than the ground temperature at a distance from the pipe. The temperature at the pipe outlet is higher than the temperature at its inlet; this is due to heat transfer from the ground to the pipe.

The ground of the surface layers of the Earth is actually a heat accumulator of unlimited capacity, the thermal conditions of which is formed under the influence of two main factors: solar radiation and the flow of radiogenic heat coming from the earth's interior. When heat is removed, the temperature of the ground around the ground heat exchanger decreases. Particular attention should be paid to the influence of the moisture content of the soil mass and the migration of moisture in its pore space on the thermal processes that determine the characteristics of the ground as a source of low-grade heat energy [5]. 
Since the heat in the ground is transmitted mainly through solid particles, water and air, as well as upon contact of the particles, the heat conduction largely depends on the mineralogical and granulometric composition, moisture and air content and density. It is known that the heat conduction increases sharply with increasing soil moisture content, since the heat conduction of air, displaced by water from the pores of the rock, is approximately 30 times less than the heat conduction of water. When all the pores are completely filled with water, the thermal conductivity of the soil reaches its maximum value. The larger the mechanical elements, the greater the thermal conductivity. Thus, the thermal conductivity of coarse-grained sand with the same porosity and moisture content twice as much as the coarse dust fraction. In terms of thermal conductivity, the solid phase of the soil is about 100 times greater than air; therefore, loose ground has a lower thermal conductivity coefficient.

The thermal conductivity of soil to a lesser extent depends on the temperature change; in the temperature range from -50 to $+50{ }^{\circ} \mathrm{C}$ it affects the interporous convection; in addition, the thermal conductivity coefficient can change by $25 \%$, while increase in the grain size from dust to coarse sand results in the rise of thermal conductivity by 2 times. For this reason, the experiment was repeated in the ground with a mass concentration of water of $1 \%, 3 \%$ and $7 \%$.

Figures 4-6 show temperature history distributions in a U-shaped pipe located in the ground with a mass concentration of moisture of $1 \%, 3 \%$ and $7 \%$.

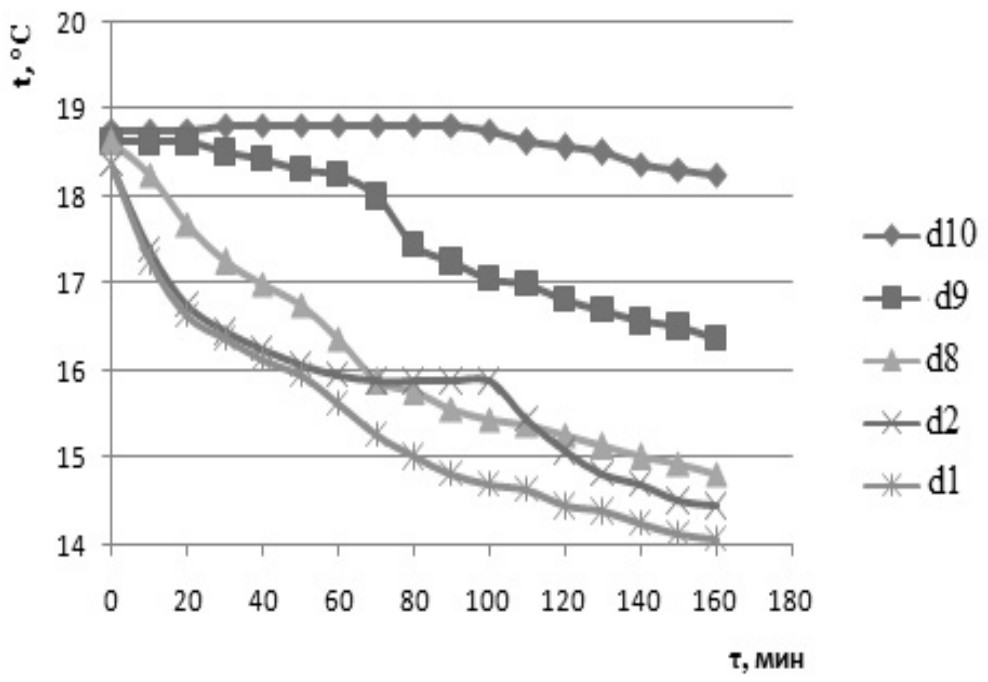

Figure 4. Temperature history distribution (moisture content of $1 \%$ )

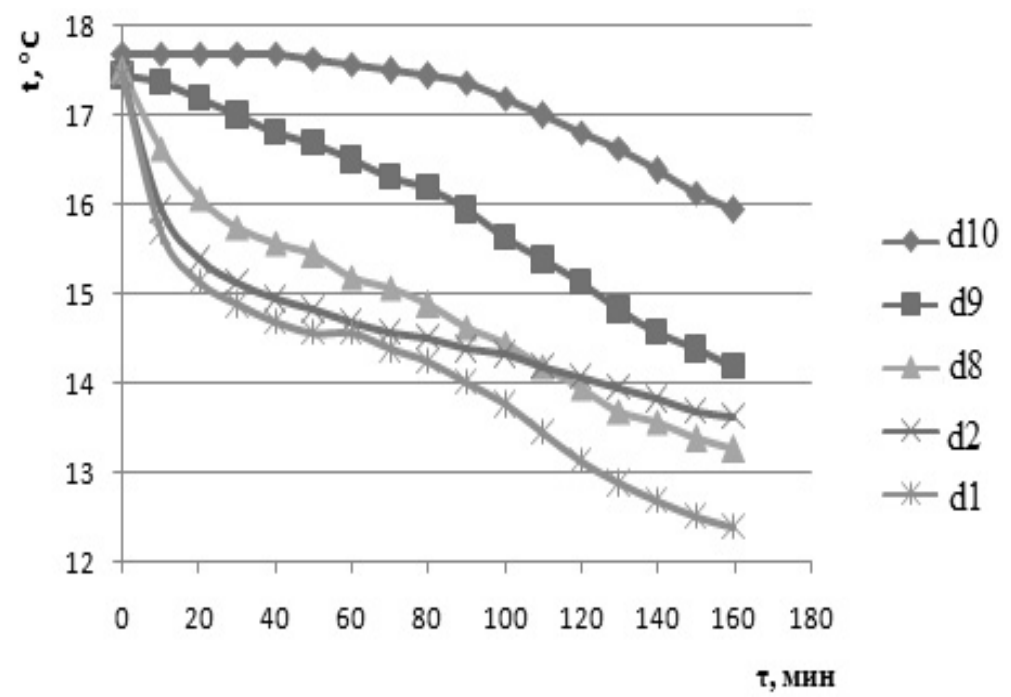

Figure 5. Temperature history distribution (moisture content of $3 \%$ ) 


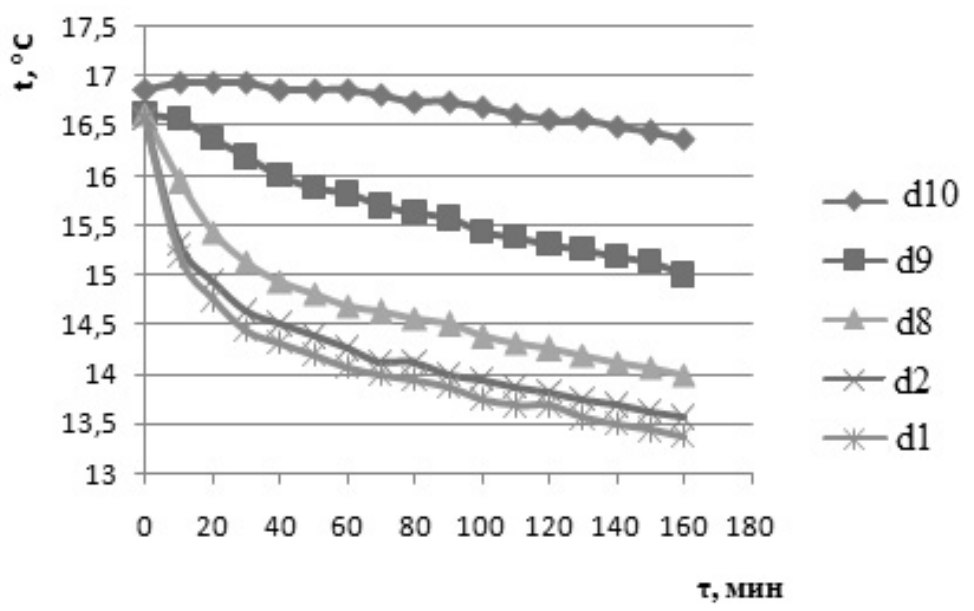

Figure 6. Temperature history distribution (moisture content of $7 \%$ )

As one can see in the figure, the sand temperature gradually decreases, and this means that the sand transfers its heat to the pipe with ice water.

Based on the results of the performed work, the following conclusions can be drawn. In dry sand, the temperature changes within an hour and a half from $19{ }^{\circ} \mathrm{C}$ to $15^{\circ} \mathrm{C}$, and in wet sand from $19{ }^{\circ} \mathrm{C}$ to $13.5^{\circ} \mathrm{C}$. It follows that wet sand increases heat removal. After half an hour, the temperature change stabilizes. The temperature difference of the sand decreases with increasing moisture content (Fig. 7).

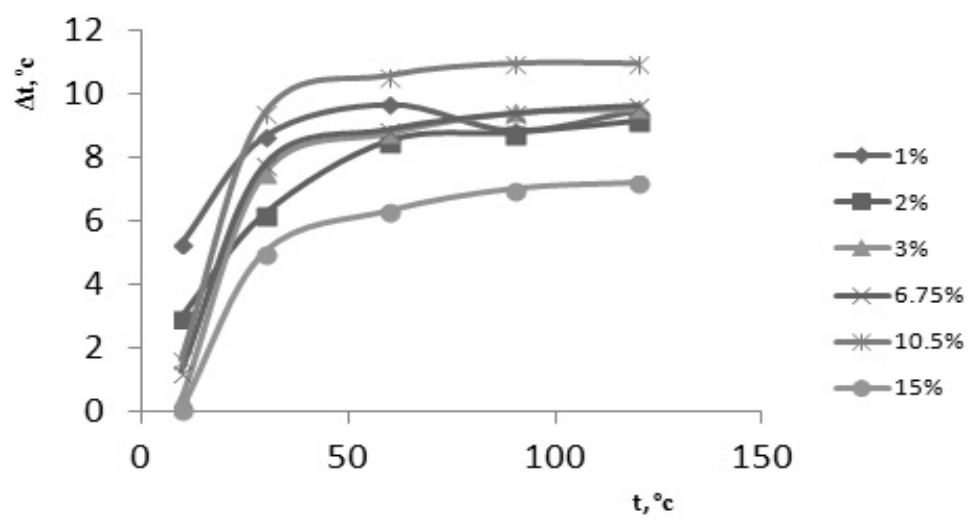

Figure 7. Dependency graph of temperature changes with temperature differences of different moisture content

The figure shows that with increasing moisture content, the temperature difference of the sand gradually increases. The reason for this is that when the sand is wet, water fills the air spaces inside the sand and facilitates the heat exchange. Therefore, when the sand moisture increases, heat is transferred to the pipe. That is, the higher the moisture content, the higher the temperature.

Since at present there are no standard heat exchangers for extracting heat from the ground, such systems should be designed for each specific object separately. It should be noted that from the point of view of thermal physics, ground is a rather complex system. By experimental studies at the test benches, the authors obtained the dependences of temperature histories of dry and wet sand and the temperature distribution in the sand in the vicinity of the polyethylene pipe. The carried out experiments confirmed that the temperature change in dry ground is greater than in wet one.

Thus, in capillary-porous systems, such as the soil mass of the heat removing system, moisture in the pore space has a noticeable effect on the process of heat distribution. The value of the equivalent thermal conductivity of moistened sand is higher than that of moistened clay, and it increases with increasing moisture content from 1 to $7 \%$. The thermal conductivity of clays varies from 2 to $4 \mathrm{~W} /\left(\mathrm{m} \cdot{ }^{\circ} \mathrm{C}\right)$, and for sand it is from $5 \mathrm{~W} /\left(\mathrm{m} \cdot{ }^{\circ} \mathrm{C}\right)$ and greater. The wetter the sand, the higher the thermal conductivity. 


\title{
References
}

1 Сибикин Ю.Д. Нетрадиционные и возобновляемые источники энергии: учеб. пособие / Ю.Д. Сибикин, М.Ю. Сибикин. - М.: КНОРУС, 2010. - 232 с.

2 Амерханов Р.А. Тепловые насосы и их роль в решении проблем энергосбережения и защиты окружающей среды / Р.А. Амерханов // Менеджер-эколог. - 2008. - № 3. - С. 65-68.

3 Шуюшбаева Н.Н. Электрогидроимпульсная технология бурения скважин при различных геологических разрезах / Н.Н. Шуюшбаева, К. Кусаиынов, Б.А. Ахмадиев, Г.С. Алтаева, Г.К. Шокимова // Знание. — 2015. — № 11-1. — С. 33-38.

4 Kusaiynov K. Study of the Heat-Transfer Processes of Tubular Elements of Ground Heat Exchangers / K. Kusaiynov, N.N. Shuyushbayeva, K.M. Shaimerdenova, Zh.G. Nurgalieva, N.N. Omarov // Journal of Engineering Physics and Thermophysics. - 2015. - Vol. 88, No. 3. - P. 676-680.

5 Kusaiynov K. Technical Physics / K. Kusaiynov, N.N. Shuyushbayeva, K.M. Shaimerdenova, B.R. Nusupbekov. — Pleiades Publishing, 2017. - Vol. 62, No. 6. - P. 867-870.

\author{
К.М. Шаймерденова, Э.Р. Шрагер, А.С. Тусыпбаева, Ж.К. Наушарбан
}

\section{Тік орналасқан жылуалмастырғыштардағы жылу алмасу үрдістерін зерттеу}

\begin{abstract}
Қазіргі таңда заман ағымына сай көптеген елдерде электр энергиясын әртүрлі жолдармен өндіруде. Жылу энергиясын өндіруде жылу сорғылары технологиясын қолдану ең тиімді энергетикалық әдістердің бірі болып табылады, яғни энергия үнемдеу мақсатында жер қойнауы жылуын, су асты суларын, су қоймаларын, табиғи су ағындарын және т.б. пайдалануға мүмкіндік береді. Бұл технологияның экологиялық тиімділігі, отын жану кезінде пайда болатын парникті газдардың сыртқа толығымен таралып кетуін болдырмауға жағдай туғызатындығынан көрінеді. Сондықтан жүйеде газ және сұйық отындарды пайдалану кезінде ескі қазандықтарды алмастырудан гөрі, жылу сорғыларының жұмыс істеу принциптері басты және өзекті мәселелердің бірі болып табылады. Ол қазу негізінде алынған отынды тұтынудың деңгейін қысқартып қана қоймай, атмосфераға бөлініп шығатын көмірқышқыл газының мөлшерін анағұрлым азайтады. «Дәстүрлі емес энергия көздері» зертханасында топырақ жылу алмастырғышында кездесетін жылу беру процестерін зерттеу үшін эксперименталды сынақ стендінде эксперименттер өткізілді. U-тәрізді топырақ жылу алмастырғыштың маңында температураны бөлу эксперименттік түрде анықталды. Олар жердегі құбырдағы температура өзгерістерін көрсетеді. Алынған деректер бойынша, тәуелділік графиктері құрылды. Температураның өзгеруі құмның ылғалдылығына байланысты анықталды. Әртүрлі ылғалдылықтағы температура айырмашылығына температура өзгерісінің графигі тұрғызылды.
\end{abstract}

Кілт сөздер: жылуалмастырғыш, жылусорғыш, жер, температура датчигі, жылуалмасу, энергия.

\author{
К.М. Шаймерденова, Э.Р. Шрагер, А.С. Тусыпбаева, Ж.К. Наушарбан
}

\section{Исследование процессов теплообмена на вертикальных теплообменниках}

\begin{abstract}
Сегодня во многих странах электроэнергия вырабатывается различными способами, в зависимости от современных тенденций. Использование технологии теплового насоса в тепловой энергии является одним из наиболее эффективных энергетических методов. С целью энергосбережения позволяет использовать подповерхностное тепло подводных вод, водохранилищ, природных водных потоков и т.д. Экологическая эффективность этой технологии заключается в том, что она помогает предотвратить выбросы парниковых газов в результате сгорания. Поэтому использование газа и жидкого топлива в системе является одной из основных и актуальных проблем эксплуатации тепловых насосов, а не замены старых котлов, что не только сократит потребление топлива, но и уменьшит количество выбросов углекислого газа в атмосферу. В лаборатории «Нетрадиционные источники энергии» были проведены эксперименты на собранном экспериментальном стенде для исследования процессов теплообмена, протекающих в грунтовом теплообменнике. Экспериментально определено распределение температуры в окрестности U-образного грунтового теплообменника. Они показывают изменения температуры вокруг трубы в грунте. По полученным данным были построены графики зависимости. Было определено изменение температуры в зависимости от различной влажности песка. Построен график зависимости изменения температуры с разницей температуры различной влажности.
\end{abstract}

Ключевые слова: теплоотдача, теплообмен, грунт, датчик температуры, теплообменник, энергия. 


\section{References}

1 Sibikin, Yu.D., \& Sibikin, M.Yu. (2010). Netraditsionnye $i$ vozobnovliaemye istochniki enerhii [Unconventional and renewable energy sources]. Moscow: Knorus [in Russian].

2 Amerkhanov, R.A. (2008). Teplovye nasosy i ikh rol v reshenii problem enerhosberezheniia i zashchity okruzhaiushchei sredy [Heat pumps and their role in solving problems of energy saving and environmental protection]. Menedzher-ekoloh Environmental Manager, 3, 65-68.

3 Shuyushbaeva, N.N., Kusaiynov, K., Akhmadiev, B.A., Altaeva, G.S., \& Shokimova, G.K. (2015). Elektrohidroimpulsnaia tekhnolohiia bureniia skvazhin pri razlichnykh heolohicheskikh razrezakh [An electric hydropulse well drilling technology for various geological sections]. Znanie - Knowledge, 11-1, 33-38.

4 Kusaiynov, K., Shuyushbayeva, N.N., Shaimerdenova, K.M., Nurgalieva, Zh.G., \& Omarov, N.N. (2015). Study of the HeatTransfer Processes of Tubular Elements of Ground Heat Exchangers. Journal of Engineering Physics and Thermophysics, 88, 3, 676-680.

5 Kusaiynov, K., Shuyushbayeva, N.N., Shaimerdenova, K.M., \& Nusupbekov, B.R. (2017). Technical Physics. Pleiades Publishing, 62, 6, 867-870. 